\title{
Long-term effects of growth hormone (GH) on body fluid distribution in GH deficient adults: a four months double blind placebo controlled trial
}

\author{
Jens Møller ${ }^{1}$, Sanne Fisker ${ }^{1}$, Anne Mette Rosenfalck ${ }^{2}$, Erik Frandsen ${ }^{3}$, Jens O L Jørgensen ${ }^{1}$, Jannik Hilsted ${ }^{2}$ \\ and J S Christiansen ${ }^{1}$ \\ ${ }^{1}$ Department of Endocrinology, Aarhus University Hospital, Kommunehospitalet 8000 Aarhus C, Denmark, ${ }^{2}$ Department of Endocrinology, \\ Hvidovre University Hospital, Copenhagen, Denmark and ${ }^{3}$ Department of Clinical Physiology, Glostrup University Hospital, Copenhagen, Denmark \\ (Correspondence should be addressed to J Møller)
}

\begin{abstract}
Objective: Short-term growth hormone $(\mathrm{GH})$ treatment normalises body fluid distribution in adult $\mathrm{GH}$ deficient patients, but the impact of long-term treatment on body fluid homeostasis has hitherto not been thoroughly examined in placebo controlled trials. To investigate if the water retaining effect of GH persists for a longer time we examined the impact of 4 months GH treatment on extracellular volume (ECV) and plasma volume (PV) in GH deficient adults.

Design: Twenty-four (18 male, 6 female) adult GH deficient patients aged 25-64 years were included and received either $\mathrm{GH}(n=11)$ or placebo $(n=13)$ in a double blind parallel design.

Methods: Before and at the end of each 4 month period ECV and PV were assessed directly using ${ }^{82} \mathrm{Br}-$ and ${ }^{125}$ I-albumin respectively, and blood samples were obtained.

Results: During GH treatment ECV increased significantly (before: $20.48 \pm 0.991,4$ months: $23.77 \pm 1.38 \mathrm{l}(P<0.01))$, but remained unchanged during placebo administration (before: $16.92 \pm$ $1.01 \mathrm{l}, 4$ months: $17.60 \pm 1.24 \mathrm{l}(P=0.37))$. The difference between the groups was significant $(P<0.05)$. GH treatment also increased PV (before: $3.39 \pm 0.27 \mathrm{l}, 4$ months: $3.71 \pm 0.26 \mathrm{l}(P=0.01)$ ), although an insignificant increase in the placebo treated patients (before: $2.81 \pm 0.18 \mathrm{l}, 4$ months: $2.89 \pm 0.20 \mathrm{l}(P=0.37))$ resulted in an insignificant treatment effect $(P=0.07)$. Serum insulin-like growth factor-I increased significantly during GH treatment and was not affected by placebo treatment. Plasma renin (mIU/l) increased during GH administration (before: 14.73 $\pm 2.16,4$ months: $26.00 \pm 6.22(P=0.03)$ ) and remained unchanged following placebo (before: $20.77 \pm 5.13$, 4 months: $20.69 \pm 6.67(P=0.99))$ leaving no significant treatment effect $(P=0.08)$.

Conclusion: The long-term impact of GH treatment on body fluid distribution in adult GH deficient patients involves expansion of ECV and probably also PV. These data substantiate the role of GH as a regulator of fluid homeostasis in adult GH deficiency.
\end{abstract}

European Journal of Endocrinology 140 11-16

\section{Introduction}

Growth hormone (GH) replacement therapy in adult GH deficient patients is associated with profound changes in body composition $(1-3)$. These changes are characterised by an increase in lean body mass and a decrease in fat mass $(4,5)$. The contribution of sodium and water retention to the increase in lean body mass is still a matter of debate. In the first studies of GH substitution to adult GH deficient patients side effects ascribed to fluid retention were frequently reported and they were subsequently shown to be dose dependent $(6,7)$. Moreover, the volume expansion during GH administration is not transient in these patients, but remains expanded for weeks (8). Studies of the more long-term impact of GH on fluid distribution in adult GH deficient patients have been scarce $(3,5,9,10)$ and uncontrolled $(5,9,10)$. The methodologies employed can be criticised because the various fluid compartments have been indirectly assessed either with total body potassium (TBK) (3) or bioelectrical impedance (BIA) $(5,9)$. When using TBK to calculate lean body mass, the assumption that intracellular concentration of potassium and protein remain constant during $\mathrm{GH}$ treatment has to be fulfilled. This is not so during $\mathrm{GH}$ administration, since GH has protein sparing as well as potassium retaining effects (11). In line with this a recent report demonstrated TBK to be a poor predictor of fat mass and fat free mass using dual energy x-ray absorptiometry as reference technique (12). The bioelectrical estimates of body composition have been shown not to correlate well with dilutional methods in adult GH deficient patients 
(10) and in normal subjects (13). Therefore, in a double blind placebo controlled study we have measured extracellular volume and plasma volume directly with ${ }^{82} \mathrm{Br}$ - and ${ }^{125}$ I-albumin respectively in $\mathrm{GH}$ deficient patients before and after four months of treatment.

\section{Materials and methods}

\section{Subjects}

Twenty-four GH deficient adult patients, aged 25-64 (median 40) years, entered the study after informed consent and approval from the local ethical committee and the Danish National Board of Health. Further clinical characteristics of the patients are given in Table 1. None of the patients had received GH during adulthood. GH deficiency was defined as peak serum GH response less than $5 \mu \mathrm{g} / \mathrm{l}$ to two provocative tests.

\section{Design}

The patients were randomised to receive either $\mathrm{GH}$ $(n=11) 2 \mathrm{IU} / \mathrm{m}^{2}$ daily (Norditropin, Novo Nordisk, Gentofte, Denmark) or placebo $(n=13)$ for four months. Before and after 4 months treatment, extracellular volume (ECV) and plasma volume (PV) were determined as follows. The patients arrived at the clinical research unit at $1900 \mathrm{~h}$. The next morning at $0800 \mathrm{~h}$ a cannula was inserted into a cubital vein for blood sampling and another cannula was inserted into an antebrachial vein on the contralateral arm for isotope infusion. Extracellular volume and plasma volume were determined using $\mathrm{Br}^{82}$ and $\mathrm{I}^{125}$-albumin respectively $(14,15) . \mathrm{Br}^{82}$ was injected at $0900 \mathrm{~h}$ and blood samples were obtained $4 \mathrm{~h}$ later. Plasma volume was determined between 1300 and 1400. Blood samples were drawn after $30 \mathrm{~min}$ rest in the supine position. The subjects were instructed not to change dietary habits and fluid intake during the study period. Twenty-four-hour ambulatory blood pressure was measured every $20 \mathrm{~min}$ in the day time (0600-2400 h) and every hour during the night using a portable automatic monitor (SpaceLabs model 90202, Redmond, WA, USA) (16). All participating females were substituted with sex hormones and were examined at mid-cycle.

\section{Assays}

Serum insulin-like growth factor-I (IGF-I) was measured by radioimmunoassay as described previously (17). The mean \pm s.E. value of IGF-I for this assay obtained in 27 age matched healthy subjects was $177 \pm 10 \mu \mathrm{g} / \mathrm{l}(18)$. Plasma renin concentrations were determined using an antibody-trapping method based on conversion of exogenous human renin substrate to angiotensin I (ANG I) in the presence of antiserum against this peptide. The amount of ANG I formed was determined in a subsequent RIA step adding ${ }^{125}$ I-ANG I and incubating overnight in the same tubes used for the enzymatic reaction. The renin concentration was calculated from the activity of a standard renin preparation incubated under identical conditions. This standard

Table 1 Clinical data of the patients. Besides being GH deficient, some patients had insufficiences of the pituitary-thyroid, pituitarygonadal and/or pituitary-adrenal axes (1, 2 or 3). Some of these patients received vasopressin (ADH).

\begin{tabular}{|c|c|c|c|c|}
\hline Sex/age (years) & $\begin{array}{c}\text { Insufficient } \\
\text { pituitary axes }\end{array}$ & $\begin{array}{c}\text { Treatment/ } \\
\text { dose reduction }\end{array}$ & Side-effects & Diagnosis \\
\hline $\mathrm{F} / 30$ & 1, $\mathrm{ADH}$ & Placebo & - & Prolactinoma \\
\hline $\mathrm{M} / 37$ & 3 & Placebo & - & Adenoma op. \\
\hline $\mathrm{M} / 28$ & 3 & Placebo & - & Adenoma op. \\
\hline $\mathrm{M} / 39$ & 0 & Placebo/50\% & Sleeplessness, myalgia & Adenoma \\
\hline $\mathrm{M} / 36$ & $3, \mathrm{ADH}$ & $\mathrm{GH} / 20 \%$ & Arthralgia & Cranio-pharyngeoma op. \\
\hline $\mathrm{F} / 31$ & $3, \mathrm{ADH}$ & $\mathrm{GH}$ & - & a.carotis int. aneur.op. \\
\hline M40 & 3 & Placebo & - & Adenoma op. \\
\hline $\mathrm{M} / 43$ & 3 & $\mathrm{GH}$ & - & Adenoma op. \\
\hline $\mathrm{M} / 29$ & $3, \mathrm{ADH}$ & Placebo & - & Cranio-pharyngeoma op. \\
\hline $\mathrm{M} / 49$ & 3 & Placebo & - & Cranio-pharyngeoma op. \\
\hline $\mathrm{M} / 56$ & 3 & $\mathrm{GH} / 50 \%$ & Edema & Adenoma op. \\
\hline $\mathrm{M} / 25$ & $3, \mathrm{ADH}$ & $\mathrm{GH}$ & - & Germinoma \\
\hline $\mathrm{M} / 30$ & $3, \mathrm{ADH}$ & $\mathrm{GH} / 40 \%$ & Edema & Adenoma op. \\
\hline $\mathrm{M} / 26$ & $3, \mathrm{ADH}$ & Placebo & - & Cranio-pharyngeoma op. \\
\hline $\mathrm{F} / 26$ & 2 & Placebo & - & Idiopathic \\
\hline $\mathrm{M} / 28$ & 2 & $\mathrm{GH}$ & - & mb. cushing \\
\hline $\mathrm{M} / 40$ & $3, \mathrm{ADH}$ & $\mathrm{GH} / 33 \%$ & Myalgia, arthralgia & Cranio-pharyngeoma op. \\
\hline $\mathrm{M} / 37$ & 0 & Placebo & - & Idiopathic \\
\hline $\mathrm{M} / 64$ & 3 & Placebo & - & Cranio-pharyngeoma op. \\
\hline $\mathrm{F} / 34$ & 1 & Placebo & - & Idiopathic \\
\hline $\mathrm{M} / 53$ & 3 & $\mathrm{GH} / 20 \%$ & Edema & Cranio-pharyngeoma op. \\
\hline $\mathrm{F} / 31$ & 1 & Placebo & - & Adenoma \\
\hline
\end{tabular}

Op, transsphenoidal operation at least once; a. carotis int aneur., arteria interna aneurysm; mb. cushing, morbus cushing. 
renin preparation 68/356 was obtained from The National Institute for Biological Standards and Control, Potters Bar, Herts, UK. All samples from each subject were run in the same assay.

\section{Statistical analyses}

SAS statistical software was employed. Student's paired $t$-test was used for within group comparisons. Simple unpaired $t$-test was used to compare the differences in delta values (i.e. baseline vs 4 months) between the two treatment groups. A $P$ value less than 0.05 was considered significant. All results are expressed as means \pm s.E.M.
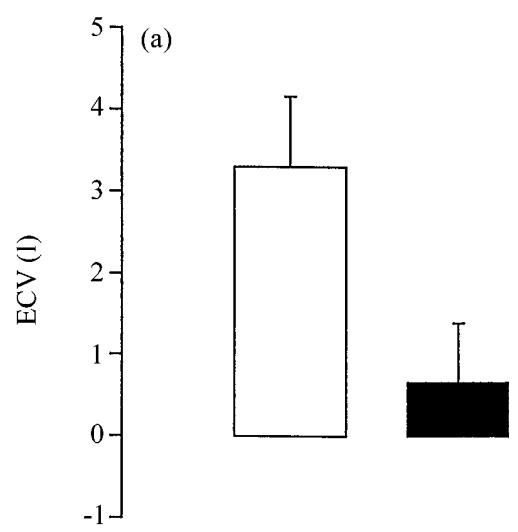

GH

Placebo

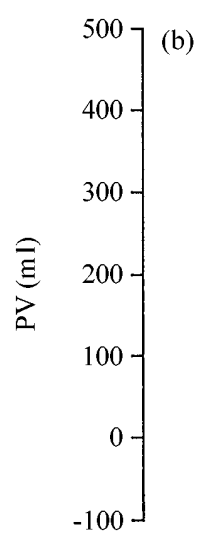

$\mathrm{GH}$

Placebo

Figure 1 (a) Changes in ECV before and after 4 months treatment with $\mathrm{GH}$ or placebo. Within group comparisons: $P<0.01(\mathrm{GH})$, $P=0.37$ (placebo); between group comparison $P<0.05$.

(b) Changes in PV before and after 4 months treatment with $\mathrm{GH}$ or placebo. Within group comparisons: $P=0.01(\mathrm{GH}), P=0.37$ (placebo); between group comparison $P=0.07$.

\section{Results}

Two out of eleven patients receiving GH ( 1 female, 1 male) were excluded due to failure with compliance. Five GH treated patients underwent dose reductions between 20 and $50 \%$, whereas one placebo treated patient had the dose reduced by $50 \%$. The mean peak $\mathrm{GH}$ response to an insulin tolerance test, a clonidine stimulation test or an arginine infusion was $0.92 \pm 0.13 \mu \mathrm{g} / \mathrm{l}$. Further data are given in Table 1 .

\section{Body composition}

Due to technical problems ECV measurements were not performed in two subjects ( 1 female, 1 male) receiving $\mathrm{GH}$ and placebo respectively. Extracellular volume (Fig. 1a) increased significantly in the GH treated patients, and remained unchanged in the placebo treated patients (Table 2). Plasma volume (Fig. 1b) increased in all 9 subjects receiving $\mathrm{GH}$ and in 8 out of 13 placebo treated patients (Table 2). Body height was significantly greater in the $\mathrm{GH}$ treated patients $(\mathrm{GH}$ $(n=9): 176.3 \pm 2.9 \mathrm{~cm}$, placebo $(n=13): 167.4 \pm 3.4 \mathrm{~cm})$ $(P<0.01)$. Body weight was not changed in the $\mathrm{GH}$ treated patients but decreased significantly in the placebo treated patients (before $\mathrm{GH}: 95.5 \pm 6.0 \mathrm{~kg}$, after GH: $94.3 \pm 6.4 \mathrm{~kg}$; before placebo: $76.2 \pm 5.6 \mathrm{~kg}$, after placebo: $75.7 \pm 7.5 \mathrm{~kg})(P<0.05)$.

\section{Plasma renin and blood pressure}

Plasma renin (Fig. 2) increased during GH treatment and remained unchanged during placebo administration (Table 2). Twenty-four-hour mean ambulatory systolic as well as diastolic blood pressure $(\mathrm{mm} \mathrm{Hg})$ was unaffected by $\mathrm{GH}$ (before GH: $122 \pm 6$ and $75 \pm 4$ respectively, after $\mathrm{GH}: 121 \pm 5$ and $73 \pm 4$ respectively)

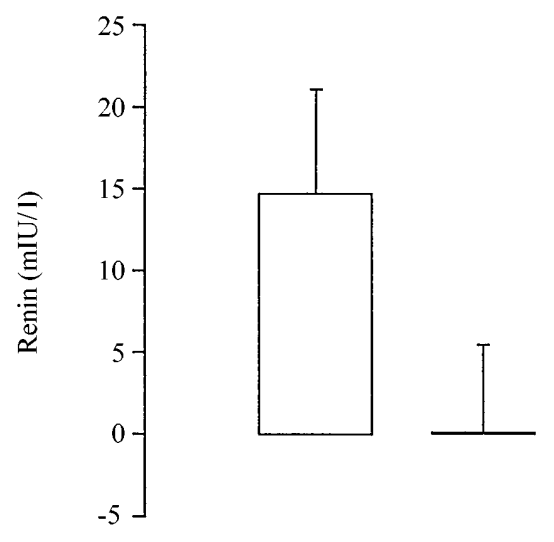

$\mathrm{GH}$

Placebo

Figure 2 Changes in plasma renin levels before and after 4 months treatment with GH or placebo. Within group comparisons: $P=0.03$ (GH), $P=0.99$ (placebo); between group comparison $P=0.08$. 
Table 2 Results of measurements of ECV, PV, renin and IGF-I in patients before and after 4 months treatment with $\mathrm{GH}$ or placebo.

\begin{tabular}{|c|c|c|c|c|}
\hline & Treatment & $\begin{array}{l}\text { Before } \\
\text { treatment }\end{array}$ & $\begin{array}{l}\text { After } 4 \text { months } \\
\text { treatment }\end{array}$ & $P$ value ${ }^{\star}$ \\
\hline $\operatorname{ECV}(\mathrm{I})(n=8)$ & $\mathrm{GH}$ & $20.48 \pm 0.99$ & $23.77 \pm 1.38$ & 0.03 \\
\hline $\operatorname{ECV}(\mathrm{I})(n=12)$ & Placebo & $16.92 \pm 1.01$ & $17.60 \pm 1.24$ & 0.03 \\
\hline $\mathrm{PV}(\mathrm{I})(n=9)$ & $\mathrm{GH}$ & $3.39 \pm 0.27$ & $3.71 \pm 0.30$ & 0.07 \\
\hline $\mathrm{PV}(\mathrm{I})(n=13)$ & Placebo & $2.81 \pm 0.18$ & $2.89 \pm 0.20$ & 0.07 \\
\hline $\operatorname{Renin}(\mathrm{mU} / \mathrm{l})$ & $\mathrm{GH}$ & $12.67 \pm 2.04$ & $27.33 \pm 7.45$ & 0.08 \\
\hline Renin (mU/l) & Placebo & $20.77 \pm 5.13$ & $20.69 \pm 6.67$ & 0.08 \\
\hline IGF-I ( $\mu \mathrm{g} / \mathrm{I})$ & GH & $106 \pm 19$ & $327 \pm 36$ & $<0.01$ \\
\hline IGF-I $(\mu \mathrm{g} / \mathrm{I})$ & Placebo & $110 \pm 17$ & $103 \pm 18$ & $<0.01$ \\
\hline
\end{tabular}

${ }^{*} P$ values are the results of between group comparisons.

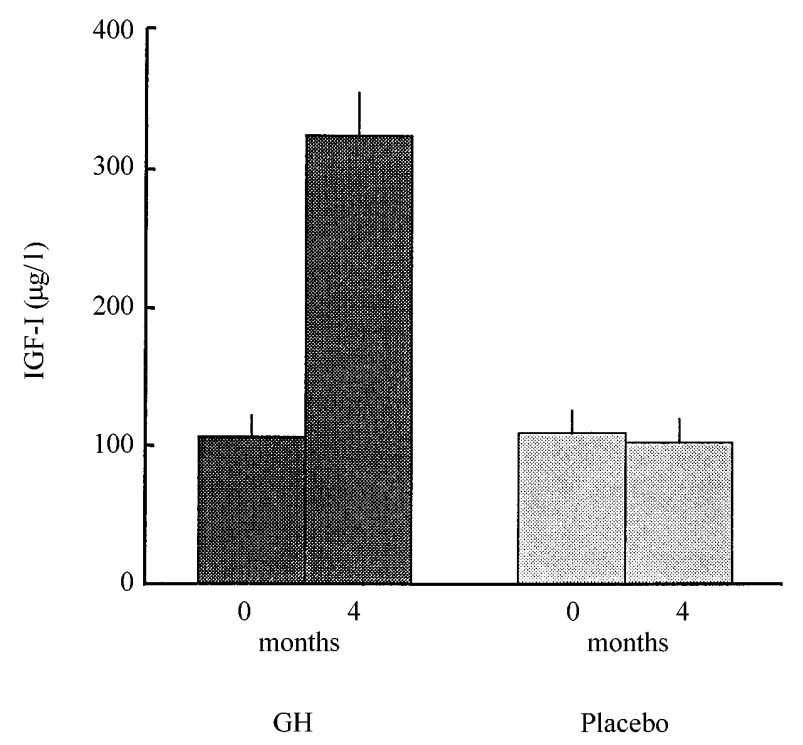

Figure 3 Mean serum IGF-I levels before and after 4 months treatment with $\mathrm{GH}$ or placebo. $P<0.01$, between group comparison.

and placebo (before placebo: $124 \pm 4$ and $77 \pm 3$ respectively, after placebo: $126 \pm 3$ and $79 \pm 3$ respectively) (not significant).

\section{IGF-I}

Mean serum IGF-I (Fig. 3) was increased by GH without being affected during placebo administration (Table 2).

\section{Discussion}

In a placebo controlled, double blind parallel study we examined the impact of 4 months GH treatment on body fluid distribution in adult GH deficient patients. Our main finding is a significant increase in ECV in the GH treated group compared with the placebo group in whom ECV remained unchanged. Plasma volume was also significantly increased in the GH treated group, but due to a small PV increase in the placebo group also the treatment effect just failed to reach statistical significance. In line with previous reports plasma renin was stimulated by GH.

Untreated adult GH deficiency has been shown to be associated with decreased ECV in several studies $(8,19$, 20) and GH substitution has been shown to normalise ECV in these patients compared with an appropriate control group (8). These observations have recently been challenged in two studies in which ECV was reported to be relatively enlarged in untreated patients $(21,22)$. In both studies, however, females were examined irrespective of the stage of their menstrual cycles which, due to the water retaining effect of sex hormones (23), may have influenced the results. Moreover, the first study included a control group where body mass index differed significantly from the patients. In the present study 5 premenopausal female subjects were examined during sex hormone substitution, thereby minimising the confounding effects of sex hormones. Recently, GH replacement for one year was shown to increase directly assessed ECV (10) in an uncontrolled study. Bengtsson et al. previously demonstrated that 26 weeks of GH therapy increased ECV (3). In that study the four compartment model was used which is dependent on a constant potassium/nitrogen ratio and a constant protein content of body cell mass of $25 \%$. There is evidence to suggest that these assumptions may not be valid in GH deficient patients (11), and measurement of total body potassium has actually been shown to be a poor predictor of lean body mass in $\mathrm{GH}$ deficient patients (12). Even so, the data obtained are comparable to results using more direct assays (6). By and large it seems appropriate to conclude that $\mathrm{GH}$ substitution in GH deficient adults is associated with a sustained increase in ECV, which probably represents a normalisation compared with the untreated state.

Plasma volume increased significantly in 9 out of 9 GH treated patients. Due to increments in the placebo treated patients the treatment effect was, however, not significant. However, in view of several previous studies in which GH induced increments in PV have been reported $(8,24,25)$ we favour the interpretation that the lack of statistical significance represents a type 2 error. In line with several previous studies plasma renin 
levels were elevated by GH but did not reach statistical significance. This finding indicates that the reninangiotensin-aldosterone system is responsible for the antinatriuretic effect of $\mathrm{GH}$, because otherwise one would anticipate feed-back suppression of the system by the GH induced volume expansion. To further support this notion we reported previously that healthy subjects receiving $\mathrm{GH}$ in combination with angiotensin converting enzyme inhibitors or aldosterone antagonists failed to increase their ECV compared with subjects receiving $\mathrm{GH}$ administration alone (26). Renin is released from the juxtaglomerular apparatus in response to decreased presentation of fluid volume in the afferent arteriole. Hence renin levels should be increased in states of volume deficiency such as GH deficiency. By contrast, plasma renin has been reported to be decreased in one patient with $\mathrm{GH}$ deficiency in whom GH treatment subsequently increased renin (27). Altogether the data indicate that GH deficient patients may exhibit an impaired function of the renin-angiotensin-aldosterone system, and that $\mathrm{GH}$ substitution acts to restore this together with normalisation of body fluid distribution.

In line with other studies (7) no changes in either diurnal systolic or diastolic blood pressure were observed.

The patients received an initial $\mathrm{GH}$ dose of $2 \mathrm{IU} / \mathrm{m}^{2}$, and subsequent dose reductions were made in $5 \mathrm{GH}$ treated patients and in 1 placebo treated patient. The mean IGF-I levels in the GH treated group were significantly higher compared with a matched group of healthy subjects, which confirms that the dosages were too high. The degree to which a more physiological replacement dose would have influenced our findings is not known, although the clinical experience is that even very low GH doses translate into substantial changes in body composition. By coincidence the gender distribution was uneven between the $\mathrm{GH}$ and the placebo groups. In the $\mathrm{GH}$ treated group only males underwent ECV measurements and only one female completed PV measurements. Male patients are more responsive to $\mathrm{GH}$ substitution in terms of IGF-I generation and changes in body composition (28), and it is therefore likely that this gender specificity also applies to ECV and PV. Future studies are needed to address this issue.

In conclusion ECV remains elevated for at least 4 months in adult GH deficient patients treated with GH. This implies that fluid retention or repletion often seen during the initial phases of GH substitution to adult $\mathrm{GH}$ deficient patients is not just a transient phenomenon but probably reflects a physiological normalisation of body composition. This effect of GH seems to be mediated through an activation of the renin-angiotensinaldosterone system.

\section{Acknowledgements}

Novo Nordisk A/S, Denmark generously supplied us with GH. We are indebted to Joan Hansen and Eva Sejr for skilful technical assistance.

\section{References}

1 Jørgensen JO, Pedersen SA, Thuesen L, Jørgensen J, Ingemann Hansen T, Skakkebaek NE et al. Beneficial effects of growth hormone treatment in GH deficient adults. Lancet $198911221-$ 1225.

2 Salomon F, Cuneo RC, Hesp R \& Sonksen PH. The effects of treatment with recombinant human growth hormone on body composition and metabolism in adults with growth hormone deficiency. New England Journal of Medicine 1989321 17971803.

3 Bengtsson BA, Eden S, Lonn L, Kvist H, Stokland A, Lindstedt G et al. Treatment of adults with growth hormone $(\mathrm{GH})$ deficiency with recombinant human GH. Journal of Clinical Endocrinology and Metabolism 199376 309-317.

4 Orme SM, Sebastian JP, Oldroyd B, Stewart SP, Grant PJ, Stickland $\mathrm{MH}$ et al. Comparison of measures of body composition in a trial of low dose growth hormone replacement therapy. Clinical Endocrinology 199237 453-459.

5 Binnerts A, Swart GR, Wilson JHP, Hoogerbrugge N, Pols HAP, Birkenhager JC et al. The effect of growth hormone administration in growth hormone deficient adults on bone, protein, carbohydrate and lipid homeostasis, as well as on body composition. Clinical Endocrinology 199237 79-87.

6 De Boer H, Blok GJ \& van der Veen EA. Clinical aspects of growth hormone deficiency in adults. Endocrine Review 199516 63-86.

7 Hoffman DM, Crampton L, Sernia C, Nguyen TV \& Ho KY. Short term growth hormone $(\mathrm{GH})$ treatment of $\mathrm{GH}$ deficient adults increases body sodium and extracellular water, but not blood pressure. Journal of Clinical Endocrinology and Metabolism 199681 1123-1128.

8 Møller J, Frandsen E, Fisker S, Jørgensen JOL \& Christiansen JS. Decreased plasma and extracellular volume in $\mathrm{GH}$ deficient adults and the acute and prolonged effects of $\mathrm{GH}$ administration. A controlled experimental study. Clinical Endocrinology 199644 533-539.

9 Amato G, Carella C, Fazio S, La Montagna G, Cittadini A, Sabatini $\mathrm{D}$ et al. Body composition, bone metabolism, and heart structure and function in growth hormone (GH) deficient adults before and after GH replacement therapy at low doses. Journal of Clinical Endocrinology and Metabolism 199377 1671-1676.

10 Janssen YJH, Deurenberg P \& Roelfsema F. Using dilution techniques and multifrequency bioelectrical impedance to assess both total body water and extracellular water at baseline and during recombinant human growth hormone $(\mathrm{GH})$ treatment in GH deficient adults. Journal of Clinical Endocrinology and Metabolism 199782 3349-3355.

11 Henneman PH, Forbes AP, Moldawer M, Dempsey EF \& Carroll EL. Effects of human growth hormone in man. Journal of Clinical Investigation 196037 1223-1245.

12 Davies JS, Bell W, Evans W, Villis RJ \& Scanlon MF. Body composition derived from whole body counting of potassium in growth hormone-deficient adults: a possible low intracellular potassium concentration. Journal of Clinical Endocrinology and Metabolism 199681 1720-1723.

13 Visser M, Deurenberg P \& van-Staveren WA. Multi frequency bioelectrical impedance for assessing total body water and extracellular water in elderly subjects. European Journal of Clinical Nutrition 199549 256-266.

14 Binder $\mathrm{C} \&$ Leth $\mathrm{A}$. The distribution volume of ${ }^{82} \mathrm{Br}-$ as a measurement of the extracellular fluid volume in normal persons. Scandinavian Journal of Clinical and Laboratory Investigation 1970 25 291-297.

15 Danielsen H, Pedersen EB, Nielsen AH, Herlevsen P, Kornerup HJ \& Posborg V. Expansion of extracellular volume in early polycystic kidney disease. Acta Medica Scandinavica 1986219 399-405.

16 Santucci S, Cates EM, James GD, Schussel YR, Steiner D \& Pickering TG. A comparison of two ambulatory blood pressure monitors, the Del Mar Avionics Pressurometer IV and the Spacelabs 90202. American Journal of Hypertension 19892 797-799. 
17 Laursen T, Møller J, Jørgensen JOL, Ørskov H \& Christiansen JS Bioavailability and bioactivity of intravenous versus subcutaneous infusion of growth hormone $(\mathrm{GH})$ in $\mathrm{GH}$ deficient patients. Clinical Endocrinology 199645 333-339.

18 Jørgensen JOL, Vahl N, Hansen TB, Skjaerbaek C, Fisker S, Ørskov $\mathrm{H}$ et al. Determinants of serum insulin-like growth factor-I in growth hormone deficient adults as compared with healthy subjects. Clinical Endocrinology 199848 479-486.

19 Rosen T, Bosaeus I, Tolli J, Lindstedt G \& Bengtson BÅ. Increased body fat mass and decreased extracellular fluid volume in adults with growth hormone deficiency. Clinical Endocrinology 199338 63-71.

20 Falkheden T \& Sjogren B. Extracellular fluid volume and rena function in pituitary insufficiency and acromegaly. Acta Endocrinologica $19644680-88$

21 van Wouters D, van Marken Lichtenbelt WD, Snel YE, Brummer RJ \& Koppeschaar HP. Deuterium and bromide dilution, and bioimpedance spectrometry independently show that growth hormone-deficient adults have an enlarged extracellular water compartment related to intracellular water. Journal of Clinical Endocrinology and Metabolism 199782 907-911.

22 Snel YE, Brummer RJ, Bol E, Doerga ME, Zelissen PMJ, Zonderland ML et al. Direct assessment of extracellular water volume by the bromide-dilution method in growth hormonedeficient adults. European Journal of Clinical Investigation 199525 $708-714$.
23 Aitken JM, Lindsay R \& Hart DM. The redistribution of sodium in women on long-term oestrogen therapy. Clinical Science 197447 179-187.

24 Linderkamp O, Butenandt O, Mader T, Knorr D \& Riegel KP. The effect of growth hormone deficiency and of growth hormone substitution on blood volume and red cell parameters. Pediatric Research $197711885-889$.

25 Christ ER, Cummings MH, Westwood NB, Sawyer BM, Pearson TC, Sonksen PH et al. The importance of growth hormone in the regulation of erythropoiesis, red cell mass, and plasma volume in adults with growth hormone deficiency. Journal of Clinical Endocrinology and Metabolism 199782 2985-2990.

26 Møller J, Møller N, Frandsen E, Wolthers T, Jørgensen JO \& Christiansen JS. Blockade of the renin-angiotensin-aldosterone system prevents growth hormone-induced fluid retention in humans. American Journal of Physiology 1997272 E803-E808.

27 Monig H, Peter M \& Sippell WG. Hyporeninaemic hypoaldosteronism after growth hormone treatment (letter). Lancet 1996347119.

28 Burman P, Johansson AG, Siegbahn A, Vessby B \& Karlsson FA. Growth hormone (GH)-deficient men are more responsive to $\mathrm{GH}$ replacement therapy than women. Journal of Clinical Endocrinology and Metabolism 199782 550-555.

Received 26 August 1998

Accepted 7 September 1998 